\title{
Medical-legal Issues Concerning Spinal Trauma
}

\author{
W. H. Donovan, M.D. \\ The Institute for Rehabilitation and Research, Texas Medical Center, 1333 \\ Moursund Avenue, Houston, Texas, U.S.A.
}

There are several areas where medical practice is affected by activities involving the legal profession. They include medical malpractice, injury prevention and consumer advocacy.

\section{Medical malpractice}

The area that has incited greatest concern is that of medical malpractice. In many countries, particularly the U.S.A. the problem of obtaining adequate insurance protection against malpractice lawsuits has reached crisis proportions. Physicians are joined by other individuals and organisations seeking liability protection in the form of casualty insurance. Indeed doctors, especially obstetricians-gynaecologists, neurosurgeons and several other surgical specialities are particularly affected, along with local and regional governmental officers, child care centre staff, accountants, architects, operators of restaurants and drinking establishments as well as various products manufacturers and transportation providers. All have been faced with limits on or cancellation of insurance and/or significant increases of premiums. In the U.S.A. from 1983 to 1985, premiums paid by doctors and hospitals went up $100^{\circ}{ }_{0}$ and $57 \%$ respectively while the Consumer Price Index and the Medical Care Index rose just $8 \%$ and $13 \%$ respectively (Olsen, 1986).

Increasing litigation is only one cause for the current situation. Others include recent and some not so recent environmental disasters, the increasingly generous awards made by judges and juries and the problems encountered by many insurance companies with the obtaining of reinsurance. Regardless of the nationality of the insurance company, much of the reinsurance is obtained from companies operating outside that country. Lloyd's of London is perhaps the largest reinsurer and $65^{\circ}$ o of reinsurance for American companies is obtained from the London market (Olsen, 1986). These companies are becoming reluctant to write policies where the risk is unpredictable such as has been the case in the U.S.A. from 1968 onward when juries seemed to become more concerned with entitlement of the plaintiff than with the actual fault of the defendant and awards began to rise significantly. All insurers have to set aside designated sums 
to prepare to meet future losses (claims). Thus it is important that they be able to predict with some accuracy these losses just as writers of life insurance and motor vehicle insurance are. When faced with needing to estimate the 'worst case scenario' for every policy, because of unpredictable large settlements, their investment capability is limited. They rely on these investments as a hedge against loss and as a means of producing income beyond the premiums charged.

Opponents of tort reform charge that the current 'crisis' is in fact overstated and in large part due to unsound business practices by the insurance companies. Opponents claim that in their desire to secure assets to invest at the high interest rates offered 5 to 10 years ago, insurers wrote policies which accepted too much risk at lower competitive rates just to obtain funds for investment. Now they are getting smaller returns and the poorer risks are 'coming home to roost'.

Advocates of tort reform have asserted that they do not believe in jeopardising an individual's right to go to court and to seek damages for a negligent act and if the court finds in his/her favour, they believe that that person deserves to be compensated for medical bills, lost earnings, verifiable additional expenses and a 'reasonable' amount for non-economic damages like pain and suffering. However, they do feel that certain conditions should apply and these include:

1. Elimination of joint and several liability (this currently permits a party to the suit with only a small per cent of responsibility to be liable for a large per cent of the judgement if other parties can't pay).

2. Limitations on non-economic damages (e.g. losses for pain and suffering, mental anguish, loss of companionship).

3. Limitations on punitive damages (some have advocated keeping them with limits and awarding them to designated agencies e.g. to compensate victims of crimes instead of awarding them to the plaintiff).

4. Periodic payments in lieu of lump sum awards for damages in excess of $\$ 100,000$.

5. Restructuring contingency fees. This feature applies only to the U.S.A. since it is the only major nation which allows them. Many reform advocates in the U.S.A. want to see this feature retained as it allows individuals to obtain and afford counsel (if their case is good enough) who would be otherwise unable to get legal assistance. However, it is subject to abuses and a sliding scale has been one recommendation where the larger the award, the smaller the per cent would be owing to the plaintiff's attorney.

6. Meaningful sanctions for filing non-meritorious suits.

7. Eliminating or modifying the collateral source rule (currently such a rule prohibits the introduction into evidence of payments already made to the plaintiff for injuries, e.g. disability income, health insurance, etc).

8. Reform of venue statues - to prevent individuals from 'shopping' for a more favourable venue (The Liability Crises in Texas, 1986).

The foregoing are just some of the changes in law that would affect malpractice litigation. It is equally important for physicians to take all the necessary steps to avoid being sued. This does not simply mean practising 'defensive medicine' which the American Medical Association estimates adds about $\$ 15$ billion to the nation's annual health care costs (The Liability Crises in Texas, 1986). Rather, such steps also include doing all that is necessary to care for the patient and communicate with him/her throughout the period of illness. 
An angry patient is more likely to bring suit and a physician can do much to allay fear, anxiety and anger by taking the time to explain to the patient, in words he can understand, what is wrong (if he knows) and what must be done to correct the problem and why. It has been said that the way to increase one's risk of being sued is to find a patient who (a) has been seriously injured or is seriously ill, (b) develops a chronic condition, and (c) is angry over the outcome. Then to such a patient, the physician should (a) communicate in a condescending or adversarial way, (b) refuse to return telephone calls and (c) send a bill in the usual way. The patient may well conclude the only way to get answers is through a lawyer (Bower, 1975; Newman, 1975).

\section{Injury prevention}

As regards injury prevention, a physician must interact with legislators and advocacy groups to effect desirable change. This subject is dealt with elsewhere in this volume, therefore, it will simply be mentioned that the main advances in prevention have been the laws (a) requiring seat belts (shoulder and lap-since lap belts alone are questionable as to their effectiveness in injury prevention), (b) pertaining to driving under the influence of alcohol or drugs and (c) raising the drinking age to 21 .

\section{Consumer advocacy}

In the field of consumer advocacy, physicians and allied health professionals have had and will continue to have a role in the enactment of legislation which insures equal rights for the handicapped. Many countries have passed laws providing for social and vocational benefits and services for injured servicemen and women, the elderly and the handicapped. In recent years awareness of the effect of architectural barriers as well as personal attitudinal barriers has increased and legislation which mandates equal access to transportation, structures and to jobs (if they qualify) for the handicapped has been passed. It is hoped this trend will continue.

\section{References}

Bower JJ 1975 How to Avoid Malpractice Suits. Medical World News 16(20):71-72 Newman GF 1975 Psychiatrist Act Has Lessons for all M.D.s. Michigan Medicine 74:273-274 Olson LL 1986 Insurance Dilema Discussed. Texas Hospitals 42:12-15

The Liability Crises in Texas 1986 Harris County Medical Society Report Oct., pp. 16-17 